\title{
Some Properties of the Immunogens (Protective Antigens) of a Single Variant of Trypanosoma brucei brucei
}

\author{
By SHEILA M. LANHAM AND ANGELA E. R. TAYLOR \\ Lister Institute of Preventive Medicine, Chelsea Bridge Road, London, SWI W $8 R H$
}

(Accepted for publication 2I March 1972)

\begin{abstract}
SUMMARY
Column-separated, clean trypanosomes were subjected to nitrogen cavitation and ultracentrifugation $(90 \mathrm{~min}, 99000 \mathrm{~g}$ ); the supernatant contained most of the immunogens but a few remained in the well washed residue. Column chromatography yielded a strongly immunogenic protein fraction (SAFI), small doses $(0.035 \mathrm{mg}$ protein/dose $\times 4)$ of which protected mice against a maximum challenge of $5 \times 10^{4}$ of the homologous variant organisms for a minimum of 17 weeks. No heterologous (variant or strain) protection was obtained with SAF I either with increased doses or by homologous challenge followed by heterologous challenge 3 weeks later. Disc electrophoresis of SAF I showed four anodic components intermediate in mobility between $\alpha$-macroglobulin and transferrin of normal rat serum. Analytical ultracentrifugation indicated a substantial proportion of $6.5 \mathrm{~S}$ protein together with $3.0 \mathrm{~S}$ and $\mathrm{I}-\mathrm{I} \cdot 5 \mathrm{~S}$ proteins. A smaller soluble antigen fraction (SAF 8) consisted of $2 \cdot 0 \mathrm{~S}$ protein but preliminary experiment has not shown it to be immunogenic. Infected rat plasma separated after $6 \mathrm{~h}$ was as effective as SAF $\mathrm{I}$ in protecting mice against homologous challenge whereas rapidly separated infected rat plasma gave only slight protection. Two identical precipitinogens were detected in infected rat plasma and SAF I by immunodiffusion. Three additional precipitinogens were present in SAF I and one other in the infected rat plasma. Antisera raised against various trypanosome fractions, including SAF I, agglutinated the homologous trypanosomes but to a lesser extent than antisera to living trypanosomes.

Incubation of trypanosomes in either SAF I, or infected rat serum or plasma decreased their infectivity which was not altered by $8 \mathrm{~h}$ of incubation in normal rat plasma.
\end{abstract}

\section{INTRODUCTION}

During the last decade, many workers (Williamson, 196r, 1963a, b; Williamson \& Desowitz, I96I; Brown \& Williamson, I962a, $b$; Seed, 1963; Seed \& Weinman, I963; Brown \& Williamson, I964; Williamson \& Brown, 1964; Gill, I965; Bigalke, I966; Lanham, I966a; Seed \& Gam, 1966; Williamson, Brown \& Brown, 1966; Njogu \& Humphryes, I967; Le Page, I968; Le Ray, 1969; Njogu, 1970; Oerlich \& Mannweiler, I970) have examined the properties of fractionated antigens from trypanosomes of the subgenus Trypanozoon. However, little attention has been paid to the immunogenic* properties of such fractions. Recently, a column-separation technique (Lanham, 1968) has allowed the preparation of large quantities of pure trypanosomes, fractionation of which has enabled us to study the immunogenic and other properties of some soluble antigens of Trypanosoma brucei brucei. The present paper details and extends our preliminary report (Taylor \& Lanham, 1972).

* Viz, capable of inducing specific immune protection (functional immunity) against a pathogenic organism (Herbert \& Wilkinson, 1971). 


\section{METHODS}

Trypanosomes. Strain o (Shinyanga III) of Trypanosoma brucei brucei, isolated in 1956 by Dr Soltys from cattle in Tanzania, was received at the Lister Institute and was either maintained by blood-passage in rats and mice, or frozen at $-196^{\circ} \mathrm{C}$. Antigenic variants were obtained from an infected rabbit by subinoculation of blood into mice. Variant b2 was isolated after 10 days and $b_{4}$ after 17 days; they were either maintained by blood-passage in rats and mice every 2 to 3 days, or stored frozen at $-196^{\circ} \mathrm{C}$.

Strain 8/18 of Trypanosoma brucei brucei, isolated in September 1962 from a pig in Eastern Nigeria, was non-infective to man (Godfrey \& Killick-Kendrick, 1967) and subsequently passaged in rats and mice or stored frozen. In January 1968 the strain was received at the Lister Institute from the Nigerian Institute for Trypanosomiasis Research and maintained in guinea-pigs prior to fly-transmission (Glossina morsitans submorsitans \& G. austeni); it was then stored frozen at $-196^{\circ} \mathrm{C}$.

Nitrogen and protein estimation. Total nitrogen was determined by a Kjeldahl-Nessler method (see Meynell \& Meynell, 1970), and was converted to total protein by multiplying by $6 \cdot 25$.

Antigen preparation. Rats were exsanguinated at peak parasitaemia under ether anaesthesia into ice-cold heparin solution (500 i.u./ml $0.95 \%$ saline) as an anticoagulant (Io i.u./ml of blood). The blood was diluted $\mathrm{I}: 3$ with ice-cold phosphate-buffered glucose-saline (PSG: $8.092 \mathrm{~g} \mathrm{Na}_{2} \mathrm{HPO}_{4}, 0.468 \mathrm{~g} \mathrm{NaH}_{2} \mathrm{PO}_{4} .2 \mathrm{H}_{2} \mathrm{O}, 2.55 \mathrm{~g} \mathrm{NaCl}$ and $10 \mathrm{~g}$ glucose, made up to I 1 in distilled water; $\mathrm{I}=0.22, \mathrm{pH} 8.0$ ) and the trypanosomes separated from the blood cells by passage through a DEAE-cellulose (Whatman Chromedia DE 52) column (Lanham, I968). The trypanosomes were then washed six times in cold PSG (by centrifuging for to min at $\mathrm{I} 600 \mathrm{~g}$ at $4^{\circ} \mathrm{C}$ ) before suspension in twice their packed cell volume of distilled water (the usual yield was about $0.5 \mathrm{ml}$ packed trypanosomes/10 $\mathrm{ml}$ blood, but could be as high as $\mathrm{I} \cdot 2 \mathrm{ml}$ ). After nitrogen cavitation (I600 p.s.i. for $20 \mathrm{~min}$ ) at $4{ }^{\circ} \mathrm{C}$ (Hunter \& Commerford, 196I) the resulting suspension of lysed trypanosomes (crude antigen $=\mathrm{CA}$ ) was stored at least overnight at $-25^{\circ} \mathrm{C}$, thus ensuring that the few surviving trypanosomes were lysed.

Fractionation of crude antigen $(C A)$. All manipulations were at $4{ }^{\circ} \mathrm{C}$. Macroparticles were sedimented from CA (after overnight dialysis against $0.04 \mathrm{M}$-phosphate buffer, $\mathrm{pH} 8 \cdot 0$ ) by centrifuging at $99000 \mathrm{~g}$ for $90 \mathrm{~min}$. A sample $(48 \mathrm{ml})$ of the supernatant (nitrogen content $1.95 \mathrm{mg} / \mathrm{ml}$ ) containing the soluble antigens (SA) was chromatographed on DEAE-cellulose (Whatman Chromedia DE 52, equilibrated with 0.04 M-phosphate buffer at $\mathrm{pH} \mathrm{8.0} \mathrm{(5.394} \mathrm{g}$ $\mathrm{Na}_{2} \mathrm{HPO}_{4}, 0.312 \mathrm{~g} \mathrm{NaH}_{2} \mathrm{PO}_{4} .2 \mathrm{H}_{2} \mathrm{O}$ made up to $\mathrm{I} 1$ in distilled water; conductivity $=0.505$ $\times 10^{4} \mu$ mho at $20^{\circ} \mathrm{C}$ ) and degassed before packing), employing a $4.5 \times 46 \mathrm{~cm}$ column with a sintered disc of porosity $\mathrm{I}$. The antigens were eluted from the column with a concave gradient of increasing ionic strength (the conductivity of the fractions was measured with a Type MCL (Mark IV) conductivity measuring bridge; Electronic Switchgear (London) Ltd). The starting buffer was $0.04 \mathrm{M}$-phosphate, $\mathrm{pH} 8 \cdot 0$, the limiting buffer was $0.8 \mathrm{M}-\mathrm{NaCl}$ in starting buffer, and the gradient established with 3 pumping tube elements of a WatsonMarlow Delta micrometering pump. The flow rate was $100 \mathrm{ml} / \mathrm{h}$ for the first $600 \mathrm{ml}$ then about $200 \mathrm{ml} / \mathrm{h}$. After discarding the first $100 \mathrm{ml}, 4 \mathrm{II} \mathrm{ml}$ of eluate were collected in $4.9 \mathrm{ml}$ fractions and the remainder in $\mathrm{I} \cdot 0 \mathrm{ml}$ fractions. Absorbance values of the fractions at $260 \mathrm{~nm}$ and $280 \mathrm{~nm}$ are shown (Fig. I); peak fractions were combined as indicated and concentrated up to 40 by ultrafiltration; soluble antigen fraction I (SAF I) showed a characteristic protein absorption spectrum (Fig. 2).

Disc electrophoresis. Polyacrylamide gel was used to analyse antigen preparations according 


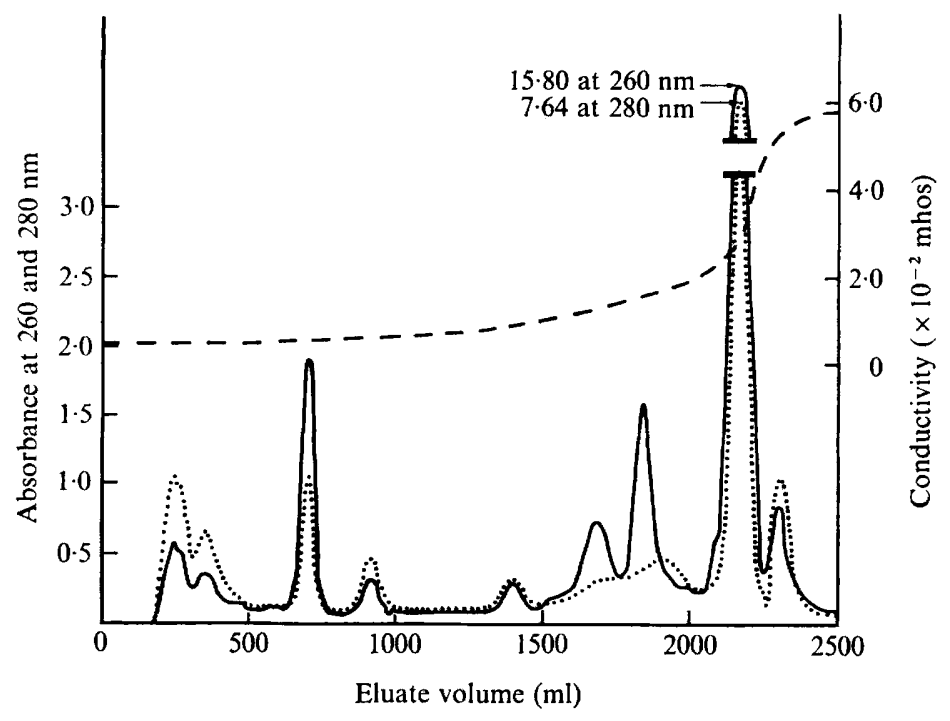

Fig. I. Concave gradient chromatography in DEAE-cellulose (DE 52) of the soluble antigens of Trypanosoma brucei brucei o variant b2. Absorbance at $260 \mathrm{~nm}-$; absorbance at $280 \mathrm{~nm} \cdots \cdot$; conductivity ---. The fractions corresponding to the separate peaks were the following eluate volumes: fraction I (SAF I), 180-438 ml (Ia, I $80-264 \mathrm{ml} ; \mathrm{Ib}, 265-352 \mathrm{ml}$; Ic, 353-438 ml); fraction 2, 440-548 ml; fraction 5, 640-713 ml; fraction 6, 714-790 ml; fraction 8, 860-955 ml; fraction II, I3 I5-15I0 ml; fraction I2, I5I I-I604 ml; fraction I3, I605-1790 ml; fraction I4, 179I-1 $890 \mathrm{ml}$; fraction 17, 2050-2242 ml; fraction 19, 2280-2347 ml. Fractions were designated 'nucleic acid' or 'protein' by calculation of their relative absorbancies at 260 and $280 \mathrm{~nm}$, and by reference to the table given in the Manual of Biochemical Methods (Conn, 1957).

to the modified method of Davies (1964): buffer, $\mathrm{pH} \times \cdot 9$ (A) $-48 \mathrm{ml} \mathrm{N}-\mathrm{HCl}, 36 \cdot 3 \mathrm{~g}$ tris, $0.46 \mathrm{ml}$ TEMED, distilled water to $\mathrm{I00} \mathrm{ml}$; acrylamide (B)-20 $\mathrm{g}$ acrylamide, $0.8 \mathrm{~g}$ bisacrylamide, distilled water to $100 \mathrm{ml}$; initiator (C)-0.004\% riboflavin; or (D) $-0.1 \%$ persulphate ammonium.

Two volumes of B were mixed with either I vol. of C and 4 vol. of distilled water, or 2 vol. of B with 4 vol. of $\mathrm{D}$ and $\mathrm{I}$ vol. of distilled water. The mixture was degassed for $\mathrm{I} O \mathrm{~min}$ on ice and I vol. of A added.

The final concentration of acrylamide was $5 \%(\mathrm{w} / \mathrm{v})$ in the gels which were polymerized for $30 \mathrm{~min}$ either by a Shandon fluorescent lamp (riboflavin initiator) or in diffuse, low intensity light (ammonium persulphate initiator). The electrode buffer was $\mathrm{pH} 8.3$ to 8.4 $(28.8 \mathrm{~g}$ glycine, $6.0 \mathrm{~g}$ tris, distilled water to $100 \mathrm{ml}$ ) and a constant current of $\mathrm{I} \mathrm{mA} /$ tube was applied for the first $5 \mathrm{~min}$ followed by $2 \mathrm{~mA} /$ tube for $90 \mathrm{~min}$ at $4{ }^{\circ} \mathrm{C}$ (the electrophoretic front was visualized, when necessary, by the addition of $\mathrm{I} \mathrm{ml} \mathrm{of} 0.00 \mathrm{I} \%$ bromophenol blue to the negative electrode buffer); during this time the voltage rose from 50 to a maximum of $\mathrm{I} 90 \mathrm{~V}$. Some of the gels were stained for $\mathrm{I}$ to $2 \mathrm{~h}$ in $\mathrm{I} \%$ naphthalene black ( $\mathrm{I} \cdot 0 \mathrm{~g}$ naphthalene black in $100 \mathrm{ml} 7 \%(\mathrm{v} / \mathrm{v})$ acetic acid) rinsed in $7 \%(\mathrm{v} / \mathrm{v})$ acetic acid and electrolytically destained for $1.5 \mathrm{~h}$ (Ward, I970) with a change of solvent after half an hour; the bands were then photographed.

Duplicate polyacrylamide preparations were used for agar-gel immunodiffusion tests, carried out in I to $\mathrm{I} \cdot 5 \%(\mathrm{w} / \mathrm{v})$ Noble agar (Difco-Bacto) in $0.9 \%$ phosphate-saline, $\mathrm{pH} 7 \cdot 0$ $\left(0.2 \mathrm{ml}\right.$ of $0.5 \mathrm{M}-\mathrm{Na}_{2} \mathrm{HPO}_{4}$ in $1500 \mathrm{ml}$ distilled water containing $\left.13.5 \mathrm{~g} \mathrm{NaCl}\right)$ and $0.065 \%$ sodium azide. The agar $(2.7 \mathrm{~mm}$ thick) was overlaid with a polyvinyl chloride mask $(0.5 \mathrm{~mm}$ thick) having a central trough wide enough to fit the polyacrylamide gel and with narrow 
troughs (I mm wide) $5 \mathrm{~mm}$ from it on either side to be filled with antisera; after loading, preparations were kept at room temperature until the antisera were absorbed, then at $4{ }^{\circ} \mathrm{C}$ for up to 7 days when the precipitin lines were photographed.

Antisera preparation. All antisera were raised in rabbits and were shown to be free of anti-rat serum components by Ouchterlony immunodiffusion against normal rat serum.

Anti-living-trypanosome serum. Trypanosome brucei brucei o variant b2 was columnseparated from infected rat blood and washed in PSG six times before intravenous inoculation of $30 \times 10^{6}$ trypanosomes into a rabbit. Blood was removed from the ear or by intracardial puncture after 7 days, allowed to clot for 24 to $48 \mathrm{~h}$ at $4{ }^{\circ} \mathrm{C}$, the serum removed by centrifugation (10 min at $500 \mathrm{~g}$ ) and stored at $-25^{\circ} \mathrm{C}$.

Anti-crude-antigen $(C A)$ serum was prepared after the method of Williamson \& Brown (1964). Equal volumes of CA in Freund's complete adjuvant (FCA) (Difco) were emulsified in two syringes connected by a single needle (double-barrelled syringe) and stored at $-25^{\circ} \mathrm{C}$. A $3.0 \mathrm{ml}$ sample of this emulsion $(5.835 \mathrm{mg}$ total nitrogen) was injected intramuscularly into a rabbit (about $2 \mathrm{~kg}$ ), half into the right fore, and half into the left hind leg, followed by similar injections into the opposite legs 7 days later. After a further 4 weeks, three intravenous injections of $0.6 \mathrm{ml}$ (I.8 ml total) alum-precipitated (Williams \& Chase, 1967) CA (I.294 mg total nitrogen) were given at 4 day intervals; blood was taken from an ear vein I week after the last injection and the serum stored at $-25^{\circ} \mathrm{C}$.

Other anti-trypanosome sera were raised to trypanosome fractions and to formalized trypanosomes with the following modifications. (i) Soluble antigen fraction (SAF I) (eluate volume 180 to $438 \mathrm{ml}$ in Fig. I). Doses of antigen were $2.0 \mathrm{ml}$ of Freund's emulsion containing $0.23 \mathrm{mg}$ antigen protein on days 0 and 7 , and $0.6 \mathrm{ml}$ alum-precipitated antigen containing $0.069 \mathrm{mg}$ protein on days 35,39 and 43 . (ii) Trypanosome metabolites (TM) were obtained by incubating living trypanosomes (washed six times in PSG) in PSG for 4 min at $37^{\circ} \mathrm{C}$ ( $15 \times 10^{8}$ trypanosomes $/ \mathrm{ml} \mathrm{PSG}$ ) and centrifuging ( $1600 \mathrm{~g}$ at $4{ }^{\circ} \mathrm{C}$ for $5 \mathrm{~min}$ ). Doses of supernatant (freshly prepared for each dose) were $4.0 \mathrm{ml}$ of Freund's emulsion containing $0.77 \mathrm{mg}$ total nitrogen, on days 0 and 7 , and $0.8 \mathrm{ml}$ of alum-precipitated antigen containing $0.144 \mathrm{mg}$ antigen nitrogen on days 35,39 and 43 . (iii) Formalized trypanosomes (FT). Washed trypanosomes were suspended in six times their volume of formol saline $(4.0 \mathrm{ml}$ $38 \%(\mathrm{w} / \mathrm{v})$ formalin solution in $96 \mathrm{ml} 0.95 \%$ saline) at room temperature for $\mathrm{I}$ to 2 days and the $\mathrm{pH}$ was adjusted to 7.0 by the addition of $0.5 \mathrm{M}$-sodium bicarbonate when necessary. The trypanosomes were finally washed and resuspended in $0.95 \%$ saline (approximately $15 \times 10^{8} / \mathrm{ml}$ ) and stored at $-25^{\circ} \mathrm{C}$. The suspension was emulsified with an equal vol. of FCA and $3.0 \mathrm{ml}$ of this injected intramuscularly into the rabbit on days 0 and 7 ; on days 35, 39 and $43,0.6 \mathrm{ml}$ of alum-precipitated formalized trypanosomes (containing $0.3 \mathrm{ml}$ of formalized trypanosome suspension) were inoculated intravenously.

Ouchterlony immunodiffusion tests. Double-diffusion precipitin tests (Ouchterlony, 1949) were carried out in I to $1.5 \%(\mathrm{w} / \mathrm{v})$ Noble agar (see Disc electrophoresis, above) which was overlaid with a polyvinyl chloride mask (Feinberg, 1964) $0.5 \mathrm{~mm}$ thick having six holes $4 \mathrm{~mm}$ diameter, $5 \mathrm{~mm}$ apart and $4 \mathrm{~mm}$ from a central hole of $7 \mathrm{~mm}$ diameter. After loading, the gels were kept at room temperature until the solutions were absorbed and then at $4{ }^{\circ} \mathrm{C}$ until fully developed (up to 7 days) when the precipitin lines were photographed.

Agglutination tests. Antisera were examined for their agglutinating properties by the method of Cunningham \& Vickerman (1962). PSG was the antisera diluent and the trypanosomes were obtained from infected blood. Suspensions, containing $7 \%(\mathrm{v} / \mathrm{v})$ glycerol added after dilution of the heparinized blood 2: I with PSG, were stored at $-196{ }^{\circ} \mathrm{C}$ in sealed lymph tubes. Single drops of serial dilutions of the antisera were plated out on siliconized 


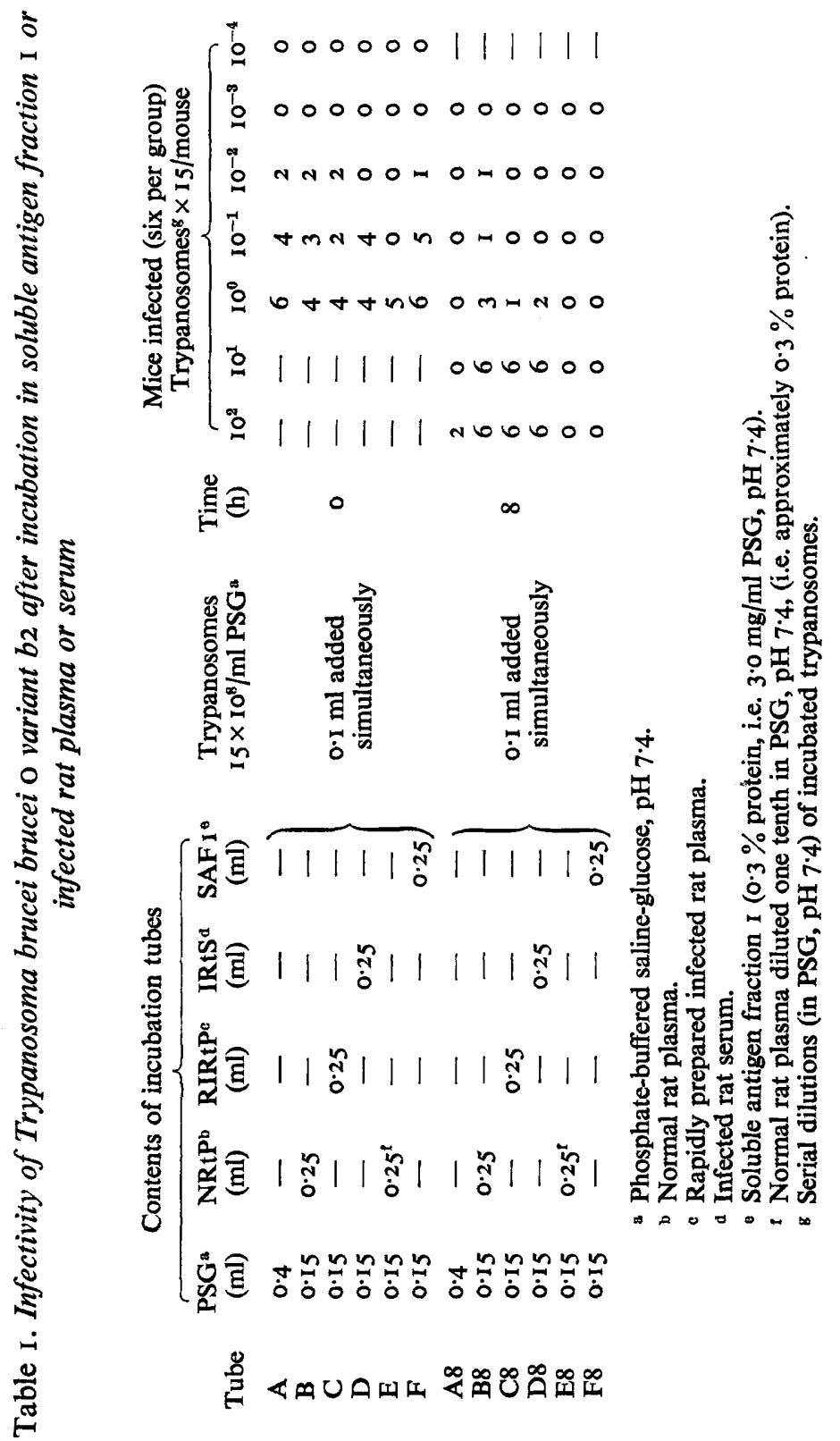


ringed slides (Adams Clay 12 ring microflocculation slides) and a drop of freshly-thawed trypanosome suspension (one lymph tube/slide) added to each dilution. The slides were kept $30 \mathrm{~min}$ in a damp chamber at room temperature, coverslips placed over the drops and the tests examined microscopically.

Immunogenic tests. The immunogenic properties of infected rat serum (IRtS) and plasma (IRtP) (see below for preparation), as well as fractions of Trypanosoma brucei brucei o variant b2, were determined in mice. IRtS, IRtP, CA, SA, and SAF I were emulsified (in a double-barrelled syringe), I vol. with I vol. of FCA and 2 vol. of PSG (dosage: rat components $=0.05 \mathrm{ml} / 0.2 \mathrm{ml} ; \mathrm{CA}=0.092 \mathrm{mg}$ nitrogen $/ 0.2 \mathrm{ml} ; \mathrm{SA}=0.2 \mathrm{mg}$ nitrogen $/ 0.2 \mathrm{ml}$; SAF $\mathrm{I}=0.035$ to $0.070 \mathrm{mg}$ protein $/ 0.2 \mathrm{ml}$ ). Sufficient emulsion was prepared for each experiment and stored at $-25^{\circ} \mathrm{C}$ (if necessary the antigen-FCA mixture was re-emulsified before dosing). Groups of 10 mice were injected intraperitoneally (i.p.) on days $0,5,15$ and $2 \mathrm{I}$; control groups included mice injected with appropriately diluted FCA or not injected. All mice were challenged 12 to 14 days after the last immunizing dose, with $5 \times 10^{2}$ trypanosomes: T. brucei brucei o, T. brucei brucei o variants b2 and b4, or T. brucei brucei 8/18/0. I ml infected blood, diluted in PSG mouse and examined daily thereafter for infection (microscopic examination of wet blood smears with $\times 40$ objective) and death. In some experiments the mice were rechallenged after 17 to 2 I days with homologous or heterologous variants and strains.

Preparation of rat components. These were reduced $2 / 3$ in volume by positive pressure dialysis, before use in the immunogenic tests.

1. Normal and infected rat serum (NRtS and IRtS). Blood from normal or infected rats at peak parasitaemia (infected 3 days previously) was allowed to clot for $6 \mathrm{~h}$ at $20{ }^{\circ} \mathrm{C}$. The serum was separated by centrifugation (Io min at $500 \mathrm{~g}$ ), filtered (Millipore APD $0.45 \mu \mathrm{m}$ ) to remove any remaining trypanosomes and stored at $-25^{\circ} \mathrm{C}$.

2. Normal (NRtP) and infected (IRtP) rat plasma. Normal or infected rats at peak parasitaemia (I or 3 day infections) were bled rapidly into ice-cold heparin solution (500 i.u./ml $0.95 \%$ saline) as an anticoagulant (10 i.u./ml blood): (a) Rapidly prepared normal (NRtP) and infected (RIRtP) rat plasma were obtained by centrifugation (I5 min at I600 $\mathrm{g}$ at $4{ }^{\circ} \mathrm{C}$ ) and filtration to remove any trypanosomes (preparation time was $35 \mathrm{~min}$ ). It was either used immediately or stored at $-25^{\circ} \mathrm{C}$; (b) slowly prepared infected rat plasma (SIRtP) was obtained as above but the blood was stood for $6 \mathrm{~h}$ at $20^{\circ} \mathrm{C}$ before being centrifuged and filtered. It was stored at $-25{ }^{\circ} \mathrm{C}$ until used.

Infectivity tests. Washed living Trypanosoma brucei brucei o variant b2 trypanosomes (see Antigen preparation), harvested from rats at high parasitaemia I day after infection, were given a final wash in PSG, $\mathrm{pH} 7 \cdot 4\left(\mathrm{I} \cdot 708 \mathrm{~g} \mathrm{NaH}_{2} \mathrm{PO}_{4} .2 \mathrm{H}_{2} \mathrm{O}, 6.938 \mathrm{~g} \mathrm{Na}_{2} \mathrm{HPO}_{4}, 2.55 \mathrm{~g} \mathrm{NaCl}\right.$, $10 \mathrm{~g}$ glucose, distilled water to $\mathrm{I} \mathrm{l}: \mathrm{I}=0 \cdot 20$ ) before being suspended in either $\mathrm{PSG}, \mathrm{pH} 7 \cdot 4$, alone or in SAF I (see Fig. I), NRtP, RIRtP, IRtS each diluted in PSG, $\mathrm{pH}_{7} \cdot 4$ (see Table I for details: see also above for preparation of rat components). Samples of these trypanosome suspensions were held on ice for immediate use in mouse infectivity tests (Lumsden et al. 1963) and the remainder were incubated at $23^{\circ} \mathrm{C}$ for $8 \mathrm{~h}$ before being similarly used (a preliminary experiment showed that $8 \mathrm{~h}$ of incubation was required for a significant decrease in infectivity after incubation in PSG, $\mathrm{pH} \mathrm{7.4}$, when compared with incubation in NRtP). After incubation trypanosome suspensions were serially diluted in ice-cold $\mathrm{PSG}, \mathrm{pH} 7 \cdot 4$, yielding five or six final suspensions ranging from $15 \times 10^{0}$ to $15 \times 10^{-4}$ or $15 \times 10^{2}$ to $15 \times 10^{-3}$ trypanosomes $/ 0.1 \mathrm{ml}$; each dilution was injected into a group of six mice $(0.1 \mathrm{ml} / \mathrm{mouse}$ i.p.). Wet blood films from the mice were examined daily for infection, and the number of deaths per group recorded. 


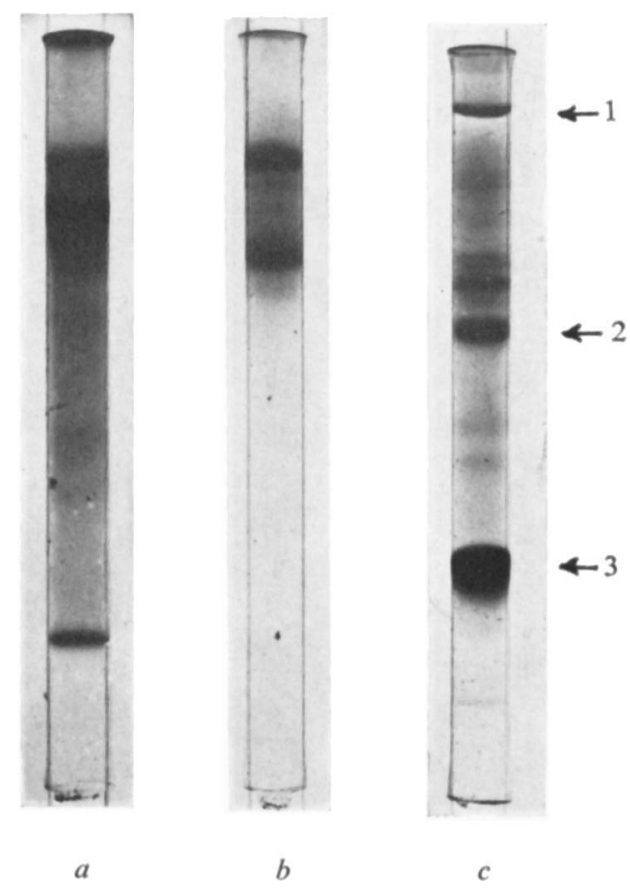

Fig. 2. Polyacrylamide disc electrophoresis of soluble antigens and normal rat serum (gels stained in I \% naphthalene black in $7 \%$ acetic acid). $a$, Soluble antigens; $b$, soluble antigen fraction I (I $80-438 \mathrm{ml}$, Fig. I); $c$, normal rat serum. $\mathrm{I}=\alpha$-macroglobulin; $2=$ transferrin; $3=$ albumin.

\section{RESULTS}

Disc electrophoresis. Electrophoresis in polyacrylamide gels separated the soluble antigens (SA) into eight discrete anodic protein bands (Fig. 2). The first fraction of SA after gradient chromatography (SAF I ; Fig. I, 3) showed four discrete anodic protein bands the mobilities of which were between the $\alpha$-macroglobulin and transferrin bands of normal rat serum run at the same time. Electrophoresis of sub-fractions of SAF I (Fig. I) showed all four protein components in SAF Ia, only three in SAF Ib (the most positively charged component was missing) and only the most negatively charged component remained in SAF Ic.

The disc electrophoretic patterns of the other fractions of SA $\left(2,5,8, \mathrm{II}_{1}, 12,14, \mathrm{I} 7\right)$ are shown in Fig. 3.

Ultracentrifugation. SAF I was scanned between 230 to $310 \mathrm{~nm}$ and showed a characteristic protein absorption spectrum (Fig. 4). Analytical ultracentrifuging (by Dr J. M. Creeth of this Institute) of a concentrated sample of this fraction ( $\mathrm{\%} \%$ protein) showed two major components (Fig. 5), the faster of which $\left(s_{20, \mathrm{w}}=6.5 \mathrm{~S}\right)$ accounted for about $60 \%$ of the total. The slower component $\left(s_{20, \mathrm{w}}=3.0 \mathrm{~S}\right)$ accounted for about $30 \%$ of the total and a still slower $\left(s_{20, \mathrm{~W}}=\mathrm{I} \cdot 0\right.$ to $\left.\mathrm{I} \cdot 5 \mathrm{~S}\right)$ approximately $10 \%$. The incomplete separation of the $6.5 \mathrm{~S}$ and $3.0 \mathrm{~S}$ components suggests the presence of a small proportion of a component with an intermediate sedimentation coefficient. The molecular weight of the $6.5 \mathrm{~S}$ component, estimated from the $s_{20, w}$ values, was 100 to $200 \times 10^{3}$ and that of the $3.0 \mathrm{~S}$ component, 25 to $50 \times 10^{3}$.

SAF 8 was a smaller protein fraction concentrated to an absorbance at $280 \mathrm{~nm}$ of 2.0 by pressure dialysis at $4{ }^{\circ} \mathrm{C}$ for $24 \mathrm{~h}$. It was probably a low molecular weight component of SA, 


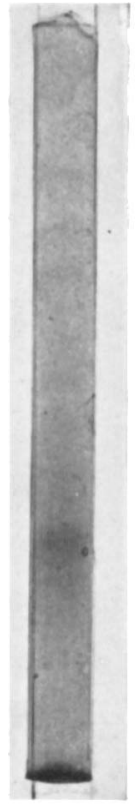

$a$

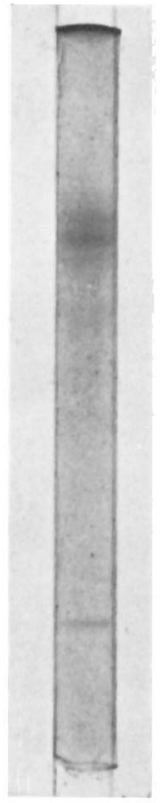

$b$

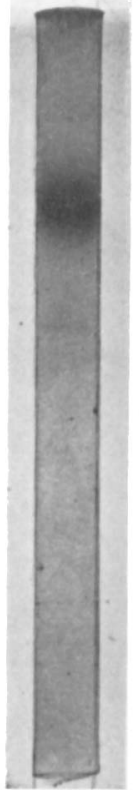

c

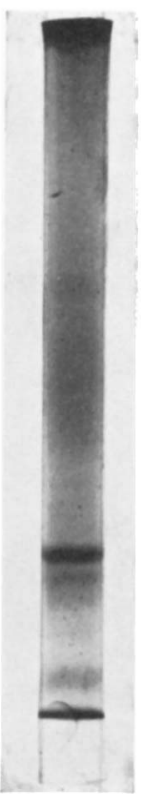

$d$

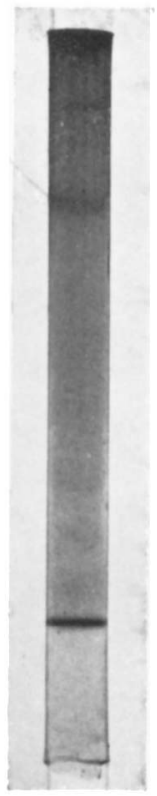

$e$

Fig. 3. Polyacrylamide disc electrophoresis of soluble antigen fractions (SAF) stained in I \% naphthalene black. $a$, SAF $_{2}(440-548 \mathrm{ml}$, Fig. I); $b$, SAF6 (714-790 ml, Fig. I); $c$, SAF8 (860-955 ml, Fig. I); $d$, SAF I (131 5-1510 ml, Fig. I); e, SAF 14 (1791-1890 ml, Fig. 1).

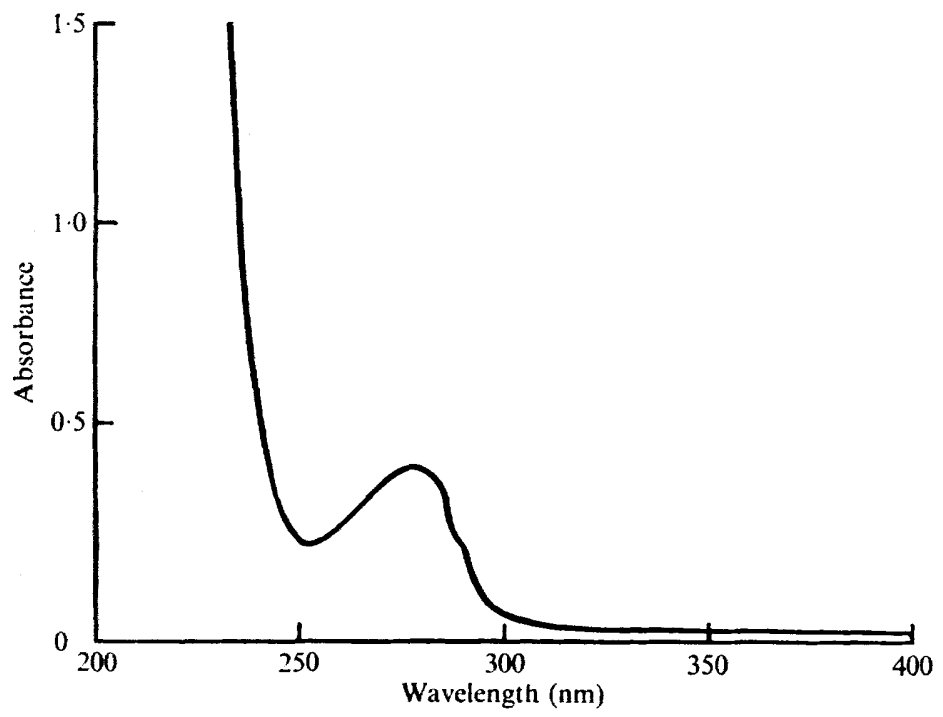

Fig. 4. The characteristic protein absorption spectrum of the soluble antigen fraction I (SAF I) from Trypanosoma brucei brucei. 


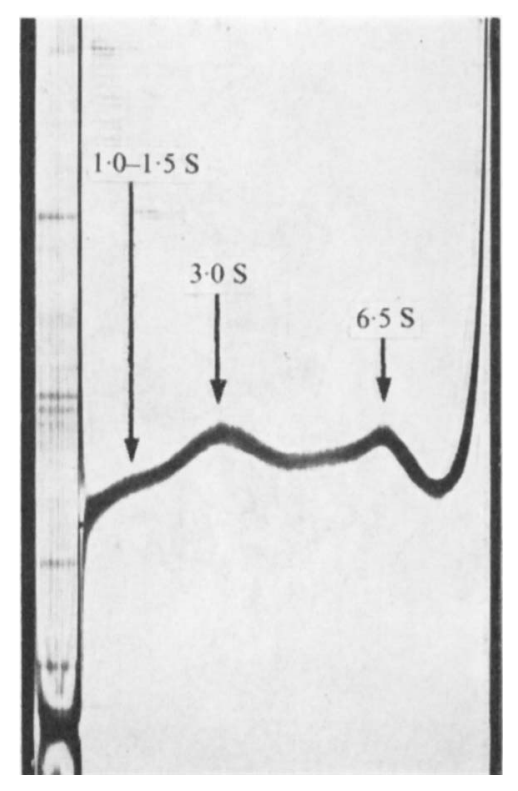

Fig. 5. Ultracentrifugal analysis of soluble antigen fraction I from Trypanosoma brucei brucei o variant b2 ( $77 \mathrm{~min}$ after attainment of operating speed; Spinco model E, $59800 \mathrm{rev} . / \mathrm{min}$; temp., $25^{\circ} \mathrm{C}$; Schlieren bar angle, $40^{\circ}$; direction of sedimentation left to right; protein concentration, $1.0 \%$ in $0.04 \mathrm{M}$-phosphate buffer containing $0.1 \mathrm{M}-\mathrm{NaCl}$ ). $\mathrm{S}$ values indicated are sedimentation coefficients corrected to $20^{\circ} \mathrm{C}$ in water.

Table 2. Trypanosoma brucei brucei o variant b2; agglutination titres with antisera to various homologous antigens

Rabbit antisera against

$\begin{array}{cccccc}\begin{array}{c}\text { Living } \\ \text { trypanosomes }\end{array} & \begin{array}{c}\text { Formalized } \\ \text { trypanosomes }\end{array} & \begin{array}{c}\text { Crude } \\ \text { antigen }\end{array} & \begin{array}{c}\text { Soluble } \\ \text { antigen }\end{array} & \begin{array}{c}\text { Soluble antigen } \\ \text { fraction I }\end{array} & \begin{array}{c}\text { Trypanosome } \\ \text { metabolites }\end{array} \\ \frac{I}{I 92000} & 0 & \frac{I}{I 530} & \frac{I}{4000} & \frac{I}{I 287} & \frac{I}{990}\end{array}$

since excessive loss of $280 \mathrm{~nm}$ absorbing material occurred during dialysis. Because of this, ultracentrifuging was carried out using a 'synthetic boundary' of the buffer solvent of SAF 8 adjusted to the same composition and conductivity. Only one peak was evident and this spread rather extensively during the course of the experiment. The sedimentation coefficient measured from the movement of the peak was approximately $s_{20, \mathrm{w}}=2 \cdot 0 \mathrm{~S}$ but the precision of this value was low owing to the base-line uncertainty from the use of this non-dialysed fraction.

Agglutinogenicity. Higher agglutination titres were obtained with antisera to living trypanosomes than to any of the various trypanosome fractions, including SAF I (Table 2). Antisera raised against formalized trypanosomes did not agglutinate living trypanosomes. Column-separation of trypanosomes, followed by six washes in PSG, did not significantly alter agglutination titres. 


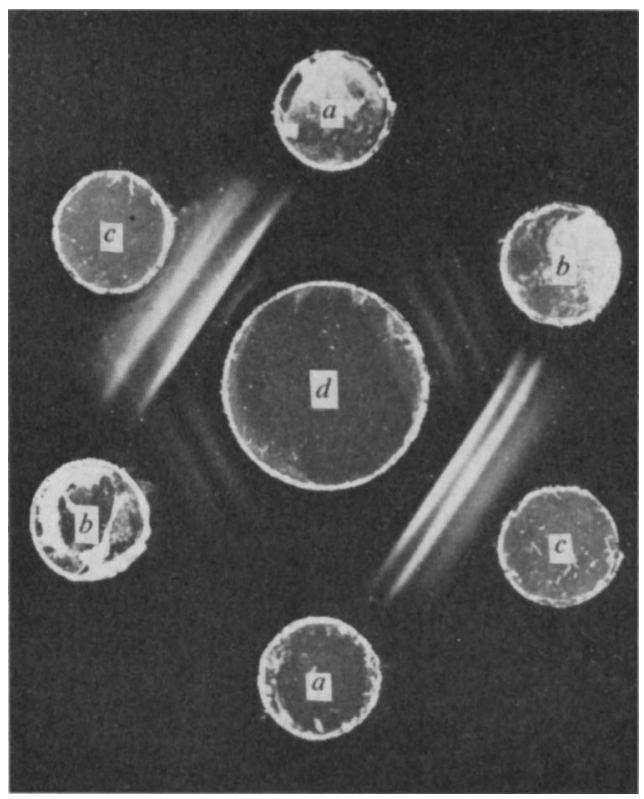

Fig. 6. Ouchterlony plate showing the build up, with time, of soluble antigens during plasma preparation; a common precipitin line is visible between these antigens and a component of soluble antigen fraction I prepared from pure trypanosomes (SAF I), $a$, Rapidly prepared infected rat plasma (RIRtP); $b$, slowly prepared infected rat plasma (SIRtP); $c$, soluble antigen fraction I (SAF I); $d$, rabbit anti-SAF I serum.

Table 3. Maximum number of precipitin lines formed during immunodiffusion of Trypanosoma brucei brucei o variant b2 fractions against antisera to homologous trypanosomes and their fractions

\begin{tabular}{|c|c|c|c|c|c|c|}
\hline \multirow[b]{2}{*}{ Antigens } & \multicolumn{6}{|c|}{ Antisera to } \\
\hline & $\begin{array}{c}\text { Living } \\
\text { trypanosomes }\end{array}$ & TM & CA & SA & SAF I & FT \\
\hline $\mathrm{TM}^{\mathbf{2}}$ & 2 & 8 & 4 & 5 & 9 & 2 \\
\hline $\mathrm{CA}^{\mathrm{b}}$ & 9 & 7 & 10 & 6 & 2 & 4 \\
\hline $\mathbf{S A}^{\mathrm{c}}$ & 9 & 9 & 9 & 6 & 7 & 4 \\
\hline SAF I $^{d}$ & 3 & 9 & 5 & 8 & 5 & 2 \\
\hline RIRtPe & 0 & 2 & I & 2 & I & 0 \\
\hline SIRtP! & $\mathbf{I}$ & 2 & 2 & 6 & 3 & $I$ \\
\hline & \multicolumn{6}{|c|}{$\begin{array}{l}\text { - Trypanosome metabolites. } \\
\text { b Crude antigen. } \\
\text { - Soluble antigen. } \\
\text { \& Soluble antigen fraction } 1 . \\
\text { e Rapidly prepared infected rat plasma. } \\
\text { - Slowly prepared infected rat plasma. }\end{array}$} \\
\hline
\end{tabular}

\section{Immunodiffusion}

I. Ouchterlony plates. Antisera to living trypanosomes contained only two precipitins against TM but nine against CA or SA and three against SAF I, antisera to formalized trypanosomes contained two precipitins against TM, four against CA and SA but only two against SAF 1. Antisera to trypanosome metabolites or fractions reacted as shown in Table 3. 
Table 4. Efficacy of immunization with Trypanosoma brucei brucei o variant b2 soluble antigen fraction $\mathrm{I}\left(S A F_{\mathrm{I}}\right)$ against graded challenges of the homologous variant

$\begin{array}{cccc}\begin{array}{c}\text { Mice dosed } \\ \text { with }\end{array} & \begin{array}{c}\text { Trypanosomes } \\ \text { per mouse } \times 5\end{array} & \begin{array}{c}\text { Mean } \\ \text { to death }\end{array} & \begin{array}{c}\text { Mortality at } \\ \text { Io days }\end{array} \\ \text { SAF I } & 10^{2} & >10 & \text { o/10 } \\ & 10^{3} & >10 & 0 / 10 \\ & 10^{4} & >10 & 0 / 10 \\ & 10^{8} & 8.0 & 9 / 10 \\ \text { FCA }^{\text {b }} \text { or undosed } & 10^{8} & 5.8 & 10 / 10 \\ & 10^{2} & 7.0 & 10 / 10 \\ & 10^{8} & 2.2 & 10 / 10\end{array}$

s In calculating the mean time to death, survivors on the tenth day were given II days of life.

- Freund's complete adjuvant.

Anti-SAF I serum contained identical precipitins against all the fractions of soluble antigens (SA) which indicated that SAF I was probably a contaminant trailing through the column during preparation.

When the anti-SA serum was tested against the infected rat plasmas only two precipitins were detected with RIRtP but six with SIRtP. Similarly with anti-SAF I serum, only one precipitin line developed against RIRtP but three with SIRtP and five with SAF I (Fig. 6). The precipitin line against RIRtP had common identity with one of those in each of SIRtP and SAF I (shown faintly in Fig. 6 but confirmed by stronger lines in other Ouchterlony plates) but the additional lines of SAF I and SIRtP were not identical with each other. With the antisera against trypanosome metabolites, although the same two lines developed against both rat plasmas, these were much enhanced with SIRtP.

2. Immunoelectrophoresis. Three to four precipitinogens were detected after disc electrophoresis of SAF I, SAF Ia, SAF Ib or SAF Ic when tested against rabbit anti-SAF I serum but only two to three precipitinogens were detected with anti-CA serum. However, disc electrophoresis gels of many other SA fractions (SAF 2, 5, II, I3, I4 and I7) showed a similar precipitinogen pattern when tested against anti-SAF I serum, thus indicating contamination with this fraction during chromatography.

Immunogenicity. Table 4 shows that SAF I protected mice against $5 \times 10^{4}$ homologous trypanosomes/mouse, but was less effective with $5 \times 10^{6}$ or $5 \times 10^{8}$ trypanosomes.

Immunization of mice with either CA, SA or SAF I of Trypanosoma brucei brucei o variant b2 (Table 5) protected them against the homologous variant but not against a heterologous variant (b4), the parent strain ( $T$. brucei brucei o) or against a recently fly-passaged strain (T. brucei brucei 8/18). Subsequent rechallenge of the protected mice (I7 to 2 I days after the first challenge) showed that the immunity was maintained but only against the homologous variant. The protection given by SAF I $(0.035 \mathrm{mg}$ protein/dose) lasted for a minimum of 17 weeks.

Mice immunized with SIRtP or IRtS were protected against homologous challenge almost as well as those mice immunized with SAF I (Table 6). On the other hand very little protection was induced with RIRtP.

Infectivity tests. The significance of the results shown in Table I was determined from the tables of Lumsden et al. (1963). Thus, there was a significant $(P>0.05)$ decrease in the infectivity of Trypanosoma brucei brucei incubated in PSG alone or in combination with RIRtP, IRtS, SAF I or dilute RIRtP; no significant difference in infectivity was obtained in trypanosomes incubated in PSG with NRtP. 


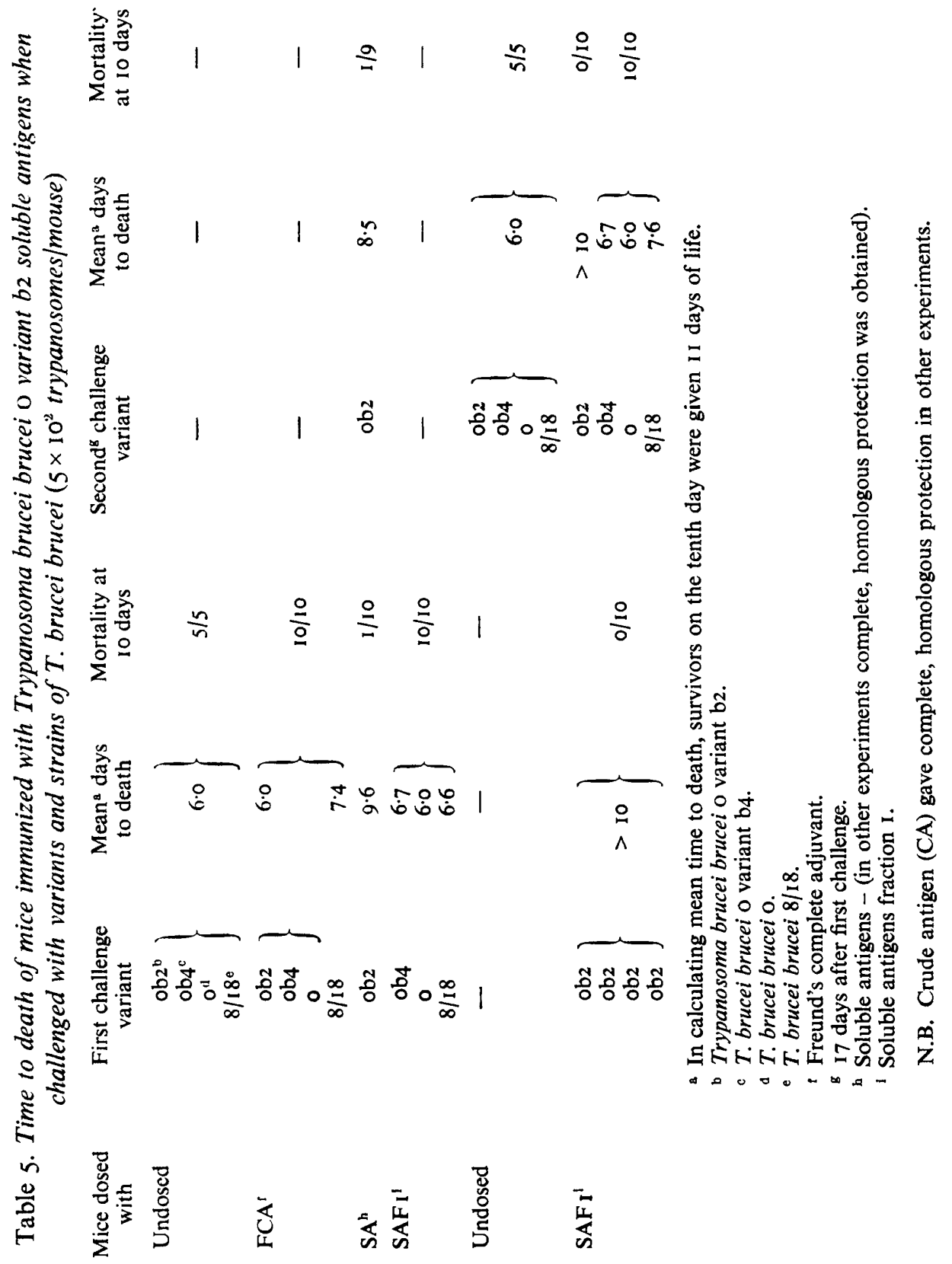


Table 6. Time to death of mice immunized with Trypanosoma brucei brucei o variant $b_{2}$ soluble antigen fraction I or infected rat plasma or serum after homologous challenge $\left(5 \times 10^{2}\right.$ trypanosomes/mouse),

\begin{tabular}{|c|c|c|}
\hline $\begin{array}{l}\text { Mice dosed } \\
\text { with }\end{array}$ & $\begin{array}{l}\text { Mean }{ }^{\mathrm{a}} \text { days } \\
\text { to death }\end{array}$ & $\begin{array}{l}\text { Mortality at } \\
\text { Io days }\end{array}$ \\
\hline RIRtPb & $6 \cdot 2$ & $6 / 9$ \\
\hline SIRtPe & $9 \cdot 3$ & $\mathrm{I} / 9$ \\
\hline $\operatorname{IRtS}^{\mathbf{a}}$ & $>10$ & $1 / 8$ \\
\hline SAF I ${ }^{2}$ & $>10$ & $0 / 10$ \\
\hline $\mathrm{NRtS}^{\mathrm{t}}$ & $4 \cdot 6$ & $10 / 10$ \\
\hline $\mathrm{FCA}^{\mathrm{g}}$ & $5 \cdot I$ & $10 / 10$ \\
\hline Undosed & $4 \cdot I$ & $10 / 10$ \\
\hline
\end{tabular}

a In calculating the mean time to death survivors on the tenth day were given I I days of life.

b Rapidly prepared infected rat plasma.

- Slowly prepared infected rat plasma.

d Infected rat serum.

e Soluble antigen fraction $\mathrm{x}$.

i Normal rat serum.

${ }^{g}$ Freund's complete adjuvant.

\section{DISCUSSION}

Most of the immunogens were in the soluble fraction of Trypanosoma brucei brucei o variant b2 and after chromatography on DEAE-cellulose, in the first fraction (SAF I), which was unaffected by frequent freezing $\left(-25^{\circ} \mathrm{C}\right)$ and thawing over a 24 month period. As far as we know, this is the first time the variant specific immunogens have been prepared directly from the trypanosomes although Lanham (1967) and Seed (1963) prepared antigens with immunogenic properties from the sera of rats infected with T. brucei brucei and T. brucei rhodesiense respectively. The purified immunogenic fraction (SAFI) contained protein but no nucleic acid. The sedimentation value of $6.5 \mathrm{~S}$ for its major component was similar to the intermediate components $(6.0$ to $6.7 \mathrm{~S}$ in fractions V and VI) seen by Njogu (1969) after agar-gel diffusion but it was higher than the values of $5.0 \mathrm{~S}$ observed by Le Page (I968) for T. brucei brucei and the variant specific $4 \cdot 0 \mathrm{OS}$ observed by Williamson $(\mathrm{I} 963 a, b)$ for $T$. brucei rhodesiense. Of the two minor antigenic components in our SAF I, one had a sedimentation value of $3.0 \mathrm{~S}$ and the other of 1.0 to $1.5 \mathrm{~S}$; these were similar to Le Page's (I968) values of $2.9 \mathrm{~S}$ and $\mathrm{I} \cdot 0$ to $2.0 \mathrm{~S}$, and Njogu's (I969) values of $3 . \mathrm{I}$ to $3.8 \mathrm{~S}$ in his fraction VII. These slight but distinct differences could be real since different strains were used; they could also be due to such factors as different methods of preparation and the aggregation of proteins or their subunits.

Some of our immunogens were probably similar to those separated by Lanham (1965, I $966 a, 1967$ ) from infected rat serum which chromatographically behaved similarly to serum globulin (IgG) and probably also corresponded to the 'exoantigen' described by Weitz $(1960 a, b)$ from IRtS, which travelled electrophoretically close to the $\gamma$-globulin position. These similarities were confirmed by a precipitin line common to IRtS, IRtP and SAF I when tested against rabbit antisera to the various fractions of pure trypanosomes, although there were additional lines of non-identity between SAFI and the rat components. The precipitin line for RIRtP was not as distinct as that for the SIRtP (Fig. 6), thus corroborating Allsopp, Njogu \& Humphryes (I97I), who found only a trace of released antigen in plasma taken as quickly as possible from an infected rat; increasing amounts appeared on standing in the presence of the trypanosomes. It seems likely therefore that trypanosomes break up 
during the preparation of infected plasma, thereby releasing their soluble antigens. This is further supported by the finding that little homologous protection was afforded to mice immunized with rapidly prepared infected rat plasma, whereas those mice immunized with either slowly prepared infected rat plasma or serum, or SAF I were well protected.

The report by Weitz ( $1960 b$ ) that 'Exoantigen (contained in IRtS) appears to be essential for the protection of the trypanosomes against adverse environmental conditions in vitro and in vivo' has not been verified by our experiments. In fact incubation of Trypanosoma brucei brucei in infected serum or plasma, or in the purified immunogens, significantly decreased their infectivity to mice whereas their infectivity was unchanged by $8 \mathrm{~h}$ of incubation in normal rat plasma. These conflicting results may have been due to use of different variants or to different methods of preparation of the plasma and sera; Weitz kept infected blood at room temperature for varying periods before the plasma or serum were removed.

Weitz (1960 b) also reported that trypanosomes which have been thoroughly washed in Alsever's solution lose their viability, agglutinability and infectivity; in our hands the infectivity and agglutinability was the same for either unwashed trypanosomes or those washed six times with PSG after column-separation from the host components. Thus the nature of the solution used for washing the trypanosomes is very important and in our experience Alsever's solution is not a good medium for trypanosomes. We have found that even after twelve washes in PSG, trypanosomes examined under the electron microscope (see Taylor \& Godfrey, 1970, for preparation technique) appeared normal and their surface coat was intact. In contrast Vickerman $(1969,1970,1972)$ reports that extensive washing in saline removes the surface coat. We believe that trypanosomes prepared rapidly in a cold, well-balanced, synthetic medium do not loose their viability, infectivity or agglutinability; morphological deterioration is minimized and in particular there is no loss of surface coat.

In our experiments (Table 2) antisera raised against trypanosome fractions or metabolites had considerably lower agglutination titres than the antisera to living trypanosomes, probably because living trypanosomes prolonged antibody induction. On the other hand, antisera raised against formalized trypanosomes did not agglutinate the homologous variant at all. Formalin reacts with the amino groups of protein and may therefore have altered the structure of the surface agglutinogens.

Although Seed \& Gam (1966) predicted that the purified protective antigens of Trypanosoma brucei gambiense would not give rise to agglutinating antibody, antiserum to our purified immunogens did agglutinate the homologous trypanosome, albeit to a lesser extent than anti-living trypanosome serum (Table 2). The results may differ because of species differences or because our immunogenic fraction is still a mixture of proteins. Further purification should settle this point.

Contrary to the results of Allsopp et al. (I97I), who could not detect released precipitinogens after Trypanosoma brucei brucei had been incubated in buffer for $6 \mathrm{~h}$, we have found precipitinogens (TM) after T. brucei brucei had been incubated in a phosphate buffer for only $4 \mathrm{~min}$. These precipitogens reacted with all our antisera. The greater release of antigens in our experiments may have been due to mechanical damage during the processing of the trypanosomes. It may be that Allsopp et al. (1971) used fewer trypanosomes or perhaps their antisera were too dilute to detect precipitinogens since these were routinely absorbed with normal rat plasma. It is however difficult to account for the non-appearance of precipitinogens after $6 \mathrm{~h}$ of incubation when we so readily detected them after only 4 min.

Our purified immunogens also induced precipitating antibody production in rabbits, whereas Seed (1963) was unable to detect precipitinogens in his preparation of protective antigen from Trypanosoma brucei rhodesiense. 
There appear to be many points of disagreement between the results of all reports on the properties of trypanosomal antigens. Doubtless methods of preparation and strain differences contribute greatly to these contradictory results. Obviously very much more information is required before such results can be extrapolated to the condition of the antigens in vivo.

This work was supported by the Overseas Development Administration of the Foreign and Commonwealth Office to whom we express our gratitude. We also are grateful to Dr D. G. Godfrey for helpful discussion and also to Mrs C. M. Scott, Mrs B. E. Rizzo, Miss S. A. Stamford, Miss P. A. Lumsden and Mr J. E. Williams for their invaluable technical assistance.

\section{REFERENCES}

Allsopp, B. A., NJoGU, A. R. \& HumphRYes, K. C. (1971). Nature and location of Trypanosoma bruce subgroup exoantigen and its relationship to $4 \mathrm{~S}$ antigen. Experimental Parasitology 29, 271-284.

BigALKE, R. D. (1966). Observations on the antigens of some trypanosomes with special reference to common antigens. Onderspoort Journal of Veterinary Research 33, 277-286.

Brown, K. N. \& Williamson, J. (1962a). Antigens of brucei trypanosomes. Nature, London 194, 1253-1 255.

Brown, K. N. \& Wiluiamson, J. (1962b). Attempts to characterize the antigens of Trypanosoma rhodesiense. Transactions of the Royal Society of Tropical Medicine and Hygiene 56, 12.

Brown, K. N. \& Williamson, J. (1964). The chemical composition of trypanosomes. IV. Location of antigens in subcellular fractions of Trypanosoma rhodesiense. Experimental Parasitology 15, 69-86.

ConN, H. J. (1957). Manual of Microbiological Methods by the Society of American Bacteriologists, p. 180. New York: McGraw-Hill.

Cunningham, M. P. \& Vickerman, K. (1962). An improved agglutination reaction for use in antigenic analysis of African trypanosomes. Transactions of the Royal Society of Tropical Medicine and Hygiene 56, $48-59$.

DAVIES, B. J. (1964). Disc electrophoresis. II. Method and application to human serum proteins. Annals of the New York Academy of Sciences 121, 404-427.

FEINBERG, J. G. (1964). A new device for immunoprecipitation in agar gels. Nature, London 20r, 631-632.

GiLL, B. S. (1965). Properties of soluble antigen of Trypanosoma evansi. Journal of General Microbiology 38 357-361.

GodFREY, D. G. \& KIILICK-KENDRICK, R. (1967). Cyclically transmitted infections of Trypanosoma brucei T. rhodesiense and T. gambiense in chimpanzees. Transactions of the Royal Society of Tropical Medicine and Hygiene 6r, 78I-79I.

Herbert, W. J. \& Wilkinson, P. C. (1971). A Dictionary of Immunology, p. 95. Oxford and Edinburgh: Blackwell Scientific Publications.

HuMPHRYes, K. C. (1970). Isoelectric focusing of Trypanosoma brucei subgroup antigens in polyacrylamide gel thin layers. A method for resolving and characterizing protein - carbohydrate complexes of an enzymic and immunological nature. Journal of Chromatography 49, 503-510.

Hunter, M. J. \& COMmerford, S. L. (1961). Pressure homogenization of mammalian tissues. Biochimica et biophysica acta 47, 580-586.

Lanham, S. M. (1966a). Chemical analysis of trypanosomal antigens. In Report of the Lister Institute of Preventive Medicine, p. II. London: Lister Institute.

LANHAM, S. M. (1966b). Fractionation of the antigens of Trypanosoma brucei. Transactions of the Royal Society of Tropical Medicine and Hygiene 60, 125-126.

LANHAM, S. M. (1967). Chemical analysis of trypanosomal antigens. In Report of the Lister Institute of Preventive Medicine, p. 14. London: Lister Institute.

LANHAM, S. M. (1968). Separation of trypanosomes from the blood of infected rats and mice by anionexchangers. Nature, London 218, 1273-1274.

Le PAGE, R. W. F. (1968). Antigenic variation in Trypanosoma brucei. Ph.D. Thesis, University of Cambridge.

LE RAY, D. (1969). Analyse immuno-électrophorétique des formes de culture de Trypanosoma brucei. Comptes rendue des séances de la Societé de Biologie 163, 2783-2787.

Lumsden, W. H. R., Cunningham, M. P., Webber, W. A. F., Van Hoeve, K. \& Walker, P. J. (1963). A method for the measurement of the infectivity of trypanosome suspensions. Experimental Parasitology I4, 269-279. 
Meynell, G. G. \& Meynell, E. (1970). Theory and Practice in Experimental Bacteriology, p. 10. Cambridge: Cambridge University Press.

Nuogu, A. R. (1969). The nature of the precipitinogens of the brucei sub-group trypanosomes. Ph.D. Thesis, London University.

Nuogu, A. R. (1970). The heterogeneity and interrelationships of the precipitating antigens of the brucei sub-group trypanosomes. Transactions of the Royal Society of Tropical Medicine and Hygiene 64, I69-170.

Njogv, A. R. \& Humphryes, K. C. (1967). Electrophoretic separation of the soluble proteins of brucei sub-group trypanosomes. Nature, London 2x6, 280-282.

Oerlich, S. \& Mannweiler, E. (1970). Präperative Isolierung von Partialantigenen aus Trypanosoma rhodesiense und Trypanosoma gambiense. Zeitschrift für Tropenmedizin und Parasitologie 21, 20-25.

OUCHTERLONY, Ö. (1949). An in vitro test of the toxin producing capacity of Corynebacterium diphtheriae. Lancet i, 346-353.

SEED, J. R. (1963). The characterization of antigens isolated from Trypanosoma rhodesiense. Journal of Protozoology 10, 380-389.

SEed, J. R. \& GAM, A. A. (1966). The properties of antigens from Trypanosoma gambiense. Journal of Parasitology 52, 395-398.

SEED, J. R. \& WEINMAN, D. (1963). Characterization of antigens isolated from Trypanosoma rhodesiense. Nature, London 198, 197-198.

TAYLOR, A. E. R. \& GoDFREY, D. G. (1970). A technique for processing trypanosomes for electron microscopy. Transactions of the Royal Society of Tropical Medicine and Hygiene 64, 189-190.

Taylor, A. E. R. \& Lanham, S. M. (1972). Partial purification of immunogenic (protective) antigens of Trypanosoma brucei brucei. Transactions of the Royal Society of Tropical Medicine and Hygiene 66, 345-346.

VICKERMAN, K. (I969). On the surface coat and flagellar adhesion of trypanosomes. Journal of Cell Science 5, $163-193$.

VICKERMAN, K. (1970). Morphological and physiological considerations of extracellular blood protozoa. In Ecology and Physiology of Parasites, p. 63. Edited by A. M. Fallis. London: Adam Hilger Ltd.

VICKERMAN, K. (1972). The host-parasite interface of parasitic protozoa, some problems posed by ultrastructural studies. Symposia of the British Society for Parasitology 10, 71-91.

WARD, S. (1970). An improved transverse destaining apparatus for acrylamide gels. Analytical Biochemistry 33, 259-262.

WeIrz, B. (1960a). A soluble protective antigen of Trypanosoma brucei. Nature, London $\mathbf{1 8 5}, 788-789$.

Werrz, B. $(1960 b)$. The properties of some antigens of Trypanosoma brucei. Journal of General Microbiology 23, 589-600.

Williams, C. A. \& Chase, M. W. (1967). Methods in Immunology and Immunochemistry, vol. I, pp. $201-202$. London and New York: Academic Press.

Williamson, J. ( I96I). Chemical composition of trypanosomes. In Report of the first seminar on fundamental research in trypanosomiasis. Annals of Tropical Medicine and Parasitology 55, 146-147.

WrLliamson, J. (I963a). The chemical composition of trypanosomes. Proceedings of the XVI International Congress of Zoology, Washington, D.C. 4, 189-195.

Wruluamson, J. (1963 b). The chemical composition of trypanosomes. II. Cytoplasmic constituents and drug resistance. Experimental Parasitology 13, 348-366.

Williamson, J. \& Brown, K. N. (1964). The chemical composition of trypanosomes. III. Antigenic constituents of brucei trypanosomes. Experimental Parasitology 15, 44-68.

Williamson, J., Brown, I. N. \& Brown, K. N. (1966). Microscale characterization of parasite antigens and antibodies by Sephadex thin-layer chromatography. Transactions of the Royal Society of Tropical Medicine and Hygiene 60, 427.

Williamson, J. \& Desowrtz, R. S. (1961). The chemical composition of trypanosomes. I. Protein, amino acid and sugar analysis. Experimental Parasitology Ir, 16I-175. 